\title{
Role of cannabinoid receptor 1 in human adipose tissue for lipolysis regulation and insulin resistance
}

\author{
Cherno O. Sidibeh ${ }^{1} \cdot$ Maria J. Pereira $^{1} \cdot$ Joey Lau Börjesson $^{1} \cdot$ Prasad G. Kamble $^{1}$ • \\ Stanko Skrtic $^{2,3} \cdot$ Petros Katsogiannos $^{1} \cdot$ Magnus Sundbom $^{4} \cdot$ Maria K. Svensson $^{1}$. \\ Jan W. Eriksson ${ }^{1}$
}

Received: 8 July 2016 / Accepted: 3 November 2016 / Published online: 17 November 2016

(C) The Author(s) 2016; This article is published with open access at Springerlink.com

\begin{abstract}
We recently showed that the peripheral cannabinoid receptor type $1(C N R I)$ gene is upregulated by the synthetic glucocorticoid dexamethasone. CNR1 is highly expressed in the central nervous system and has been a drug target for the treatment of obesity. Here we explore the role of peripheral CNR1 in states of insulin resistance in human adipose tissue. Subcutaneous adipose tissue was obtained from well-controlled type 2 diabetes subjects and controls. Subcutaneous adipose tissue gene expression levels of CNR1 and endocannabinoid synthesizing and degrading enzymes were assessed. Furthermore, paired human subcutaneous adipose tissue and omental adipose tissue from non-diabetic volunteers undergoing kidney donation or bariatric surgery, was incubated with or without dexamethasone. Subcutaneous adipose tissue obtained from volunteers through needle biopsy was incubated with or without dexamethasone and in the presence or absence of the CNR1-specific antagonist AM281. CNR1 gene and protein expression, lipolysis and glucose uptake were evaluated. Subcutaneous adipose tissue CNRI gene expression
\end{abstract}

Electronic supplementary material The online version of this article (doi:10.1007/s12020-016-1172-6) contains supplementary material, which is available to authorized users.

\footnotetext{
$\checkmark$ Jan W. Eriksson

jan.eriksson@medsci.uu.se

1 Department of Medical Sciences, Uppsala University, Uppsala, Sweden

2 AstraZeneca R\&D, Mölndal, Sweden

3 Department of Endocrinology, Institute of Medicine, Sahlgrenska Academy, University of Gothenburg, Gothenburg, Sweden

4 Department of Surgical Sciences, Uppsala University, Uppsala, Sweden
}

levels were 2-fold elevated in type 2 diabetes subjects compared with control subjects. Additionally, gene expression levels of CNRI and endocannabinoid-regulating enzymes from both groups correlated with markers of insulin resistance. Dexamethasone increased $C N R 1$ expression dose-dependently in subcutaneous adipose tissue and omental adipose tissue by up to 25 -fold. Dexamethasone pre-treatment of subcutaneous adipose tissue increased lipolysis rate and reduced glucose uptake. Co-incubation with the CNR1 antagonist AM281 prevented the stimulatory effect on lipolysis, but had no effect on glucose uptake. CNR1 is upregulated in states of type 2 diabetes and insulin resistance. Furthermore, CNR1 is involved in glucocorticoid-regulated lipolysis. Peripheral CNR1 could be an interesting drug target in type 2 diabetes and dyslipidemia.

Keywords Type 2 diabetes $\cdot$ Glucocorticoids $\cdot$ Insulin resistance $\cdot$ Adipose tissue $\cdot$ Endocannabinoid system

$\begin{array}{ll}\text { Abbreviations } \\ \text { 2-AG } & \text { 2-Arachidonoylglycerol } \\ \text { ACEA } & \text { Arachidonyl-2'-chloroethylamide } \\ \text { AM281 } & \begin{array}{l}\text { 1-(2,4-Dichlorophenyl)-5-(4-iodophenyl)-4- } \\ \text { methyl- } N \text {-4-morpholinyl-1H-pyrazole-3- } \\ \text { carboxamide }\end{array} \\ \text { AEA } & \begin{array}{l}\text { Anandamide } \\ \text { CNR1 }\end{array} \\ \text { Cannabinoid receptor type 1 } \\ \text { CNR2 } & \text { Cannabinoid receptor type 2 } \\ \text { DAGL } & \text { Diacylglycerol lipase } \\ \text { ERK } & \text { Extracellular signal-regulated kinase } \\ \text { FAAH } & \text { Fatty acid amide hydrolase } \\ \text { HSL } & \text { Hormone-sensitive lipase } \\ \text { KRH } & \text { Krebs-Ringer media } \\ \text { MAPK } & \text { Mitogen-activated protein kinase }\end{array}$

\section{Abbreviations}

2-AG 2-Arachidonoylglycerol

ACEA Arachidonyl-2'-chloroethylamide

$\begin{array}{ll}\text { AM281 } & \text { 1-(2,4-Dichlorophenyl)-5-(4-iodophenyl)-4 } \\ \text { methyl- } N \text {-4-morpholinyl-1 } H \text {-pyrazole-3- }\end{array}$ carboxamide

AEA Anandamide

Cannabinoid receptor type 1

CNR2 Cannabinoid receptor type 2

DAGL Diacylglycerol lipase

ERK Extracellular signal-regulated kinase

FAAH Fatty acid amide hydrolase

HSL Hormone-sensitive lipase

MAPK Mitogen-activated protein kinase 
MGL Monoacylglycerol lipase

NAPE- $\quad N$-acyl phosphatidylethanolamine phospholi-

PLD pase D

OAT Omental adipose tissue

SAT Subcutaneous adipose tissue

T2D Type 2 diabetes

\section{Introduction}

Obesity and type 2 diabetes (T2D) are recognized as major health problems of epidemic proportions worldwide. Obesity, in particular central obesity, increases the risk of cardiovascular disease, insulin resistance and T2D. It is estimated that globally more than 1.9 billion adults are overweight and $9 \%$ of adults are diabetic [1]. From a public health perspective it is of interest to identify and explore mechanisms and potential treatment concepts that are common for insulin resistance and obesity because of their shared association with the onset of T2D.

Glucocorticoids are steroid hormones whose synthetic analogs are used clinically for the treatment of autoimmune or inflammatory conditions [2]. Due to their immunosuppressive properties they are also used in transplant patients to prevent graft rejection. However, elevated plasma glucocorticoid levels, such as in Cushing's syndrome or during long-term treatment, are associated with several adverse effects such as obesity, dyslipidemia, insulin resistance, and the onset of T2D [3]. The identification of glucocorticoidregulated genes that are associated with insulin resistance or obesity can provide novel pharmacological approaches for such conditions. In a previous microarray study [4], using a model of insulin resistance by incubating human adipose tissue with the synthetic glucocorticoid dexamethasone, cannabinoid receptor type 1 (CNRI) was identified as one of the genes with the greatest increase in expression in subcutaneous and omental adipose tissue (SAT and OAT, respectively). CNR1 is a member of the cannabinoid receptor family and the superfamily of $G$ protein-coupled receptors recognized to activate multiple signaling pathways regulating cell survival/death and energy metabolism [5]. The highest expression levels of CNRI are observed in different brain regions, but it is also present at lower levels in most other cells/tissue types, including adipose tissue [6, 7].

The endocannabinoid system, composed of CNR1 and CNR2, their lipid ligands (endocannabinoids) 2arachidonoylglycerol (2-AG) and anandamide (AEA), and the endocannabinoid synthesis and degrading enzymes; plays an important role in the regulation of energy homeostasis $[8,9] .2-A G$ is synthesized by diacylglycerol lipase (DAGL) and degraded by monoacylglycerollipase (MGL). While AEA is synthesized by $N$-acyl phosphatidylethanolamine phospholipase D (NAPE-PLD) and degraded by fatty acid amide hydrolase (FAAH) [10]. DAGL enzymes are encoded by two separate genes, denoted DAGL-ALPHA and DAGLBETA.

An association between glucocorticoids and the endocannabinoid system has previously been demonstrated; where glucocorticoids elevate expression of endocannabinoids in regulation of the hypothalamic-pituary-adrenal axis [9, 11]. CNR1 regulates food intake in the hypothalamus [12] and in obesity the endocannabinoid/CNR1 system is upregulated, both centrally and peripherally $[13,14]$. Given the role of CNR1 in obesity, antagonists have been developed as anti-obesity drugs. In 2006, a potent and selective CNR1-antagonist, rimonabant, was approved for treatment of obesity and for overweight patients with metabolic comorbidities such as T2D [15]. However, due to reported side effects such as depression and anxiety, rimonabant was withdrawn from the market [16]. Although the association between the central and peripheral levels of CNR1 and obesity has been demonstrated, it is uncertain if an increase of CNR1 in adipose tissue is sufficient to induce changes in glucose and lipid metabolism. Prior studies have attempted to separate the brain effects of endocannabinoids from their peripheral effects $[17,18]$. However, these studies have been inconclusive since they have lacked a peripherally restricted CNR1 antagonist.

In this study we aim to investigate if CNR1 is a factor associated with the development of insulin resistance in adipose tissue by the examination of the endocannabinoid system in freshly harvested SAT from healthy control vs. T2D subjects. In addition, we aim to, via glucocorticoidinduced insulin resistance by long-term incubation (24 h) of SAT; investigate whether CNR1 plays a role in the regulation of glucose and lipid metabolism in human adipocytes.

\section{Materials and methods}

\section{Adipose tissue donors}

A cohort of 20 T2D subjects was group-wise matched with 20 non-diabetic subjects by gender $(10 \mathrm{~F} / 10 \mathrm{M})$, age $(58 \pm 9$ vs. $58 \pm 11)$ and body mass index (BMI) $(30.7 \pm 4.9$ vs. $30.8 \pm 4.6 \mathrm{~kg} / \mathrm{m}^{2}$ ) [19]. Fasting blood samples, and oral glucose tolerance test (OGTT) and SAT needle biopsies were performed as previously described [19]. SAT was acquired by needle aspiration of the lower abdominal region and used to assess the endocannabinoid system and measure adipocyte glucose uptake [19]. Clinical and biochemical characteristics of the subjects are shown in Supplementary Table 1. A schematic view of the study is given in Supplementary Fig. 1A. 
In a separate cohort, paired samples of human SAT and OAT were obtained from non-diabetic subjects with a wide distribution of BMI and insulin sensitivity (13M/31F, 24-66 years, BMI $20.7-56.3 \mathrm{~kg} / \mathrm{m}^{2}$ ) undergoing kidney donation $(n=35)$ at the Sahlgrenska University Hospital or bariatric surgery $(n=9)$ at the Uppsala University Hospital. Paired SAT and OAT were used to study the CNRI mRNA expression levels $(n=41)$ and the effects of dexamethasone on CNR1 mRNA $(n=30)$ and protein expression $(n=5)$ and glucose uptake $(n=12-21)$. In addition, SAT was obtained from a separate group of non-diabetic volunteers $(5 \mathrm{M} / 21 \mathrm{~F}$, 21-72 years, BMI $21.3-32.9 \mathrm{~kg} / \mathrm{m}^{2}$ ) by needle aspiration of the abdomen after local dermal anesthesia with lidocaine (Xylocain; AstraZeneca, Sweden). These adipose tissue samples were used to study the effects of dexamethasone treatment and a CNR1-antagonist or CNR1-agonist on adipocyte lipolysis $(n=19)$ and glucose uptake $(n=12)$. Due to limited amounts of adipose tissue obtained from biopsies, not all experiments were performed on samples from every subject. A representative schematic view of this part of the study is given in Supplementary Fig. 1B.

Fasting blood samples were collected for analysis of plasma glucose, insulin and lipids at the Department of Clinical Chemistry at the respective hospitals. Subjects with type 1 diabetes and/or T2D, other endocrine disorders, cancer or other major illnesses, as well as ongoing medication with beta-adrenergic blockers, systemic glucocorticoids or immune-modulating therapies were excluded from the study. Eighteen individuals were positive for having first-degree relatives with T2D. Among the 52 female subjects, 24 were pre-menopausal. Clinical and biochemical characteristics of the subjects are shown in Supplementary Table 2. Most of the subjects included in the lipolysis experiments were females (Supplementary Table 3).

The study protocols were approved by the Regional Ethics Review Boards in Gothenburg (Dnr 336-07) and Uppsala (Dnr 2013/330 and Dnr 2013-183/494). Written informed consent was obtained from all study participants.

\section{Endocannabinoid system in freshly harvested SAT}

Immediately after the biopsies, the SAT from T2D and control subjects was snap frozen in liquid nitrogen. The gene expression levels of CNRI and the major enzymes responsible for the synthesis and degradation of the two principal endocannabinoids, 2-AG and AEA, was measured. 2-AG levels in SAT were also assessed but AEA levels were not detectable. Gene expression levels were obtained with RNA-Seq at Exiqon A/S, Vedback, Denmark and 2-AG quantification was done by Metabolon Inc's (Durham, North Carolina, USA) TrueVision ${ }^{\mathrm{TM}}$ as previously described [19].

\section{Adipose tissue incubation and assessments}

Paired samples of SAT and OAT were cut into small pieces and incubated in DMEM containing $6 \mathrm{mM}$ glucose (Invitrogen Corporation, Paisley, UK), $10 \%$ FBS (Invitrogen) and $1 \%$ PEST (Invitrogen) with or without the addition of dexamethasone (Sigma-Aldrich, St. Louise, MO, USA) at varying concentrations $(0.003-3 \mu \mathrm{M})$, to assess the doseresponse, or at a single optimal concentration $(0.3 \mu \mathrm{M})$ for $24 \mathrm{~h}$ in $37^{\circ} \mathrm{C}, 5 \% \mathrm{CO}_{2}$. Following incubation, part of the adipose tissue was snap-frozen for CNRl gene (real-time PCR) or protein (immunohistochemistry) expression analysis. Other parts of the incubated adipose tissue were used to isolate adipocytes with collagenase (Sigma), as previously described [20,21], and glucose uptake was assessed in isolated adipocytes.

In addition, SAT was incubated in DMEM $(6 \mathrm{mM}$ glucose, $10 \%$ FBS, $1 \%$ PEST) with or without the glucocorticoid cortisol or dexamethasone $(1 \mu \mathrm{M}$ for both) and CNR1 gene expression was measured. The potency of dexamethasone is $\sim 5$ times higher than cortisol, assessed as effects on $\beta$-adrenergic receptor expression (EC50 4.8 $\mathrm{nmol} / \mathrm{L}$ for dexamethasone $24 \mathrm{nmol} / \mathrm{L}$ for cortisol) [22], and we have internal data showing a similar potency difference (not shown). Thus, $0.3 \mu \mathrm{M}$ concentration of dexamethasone would correspond to a maximum physiological level of cortisol under stress conditions of about 1-2 $\mu \mathrm{M}$ [23]. To ensure a maximal effect on $C N R 1$ expression and compare the effects of dexamethasone and its natural glucocorticoid cortisol in CNRI mRNA expression, $1 \mu \mathrm{M}$ was used. Moreover, SAT was incubated in DMEM (6 mM glucose, $10 \% \mathrm{FBS}, 1 \% \mathrm{PEST}$ ) with or without dexamethasone $(0.3 \mu \mathrm{M})$ for $24 \mathrm{~h}$ in $37^{\circ} \mathrm{C}, 5 \% \mathrm{CO}_{2}$ and with or without the CNR1 antagonist/inverse agonist AM281 (1-(2,4-dichlorophenyl)-5-(4-iodophenyl)-4-methyl- $N$-4-morpholinyl-1 $H$ pyrazole-3-carboxamide, Sigma, $3 \mu \mathrm{M}$ ) for the final $4 \mathrm{~h}$ of incubation. SAT was also incubated with or without the CNR1 agonist ACEA (Arachidonyl-2'-chloroethylamide, Cayman, $1 \mu \mathrm{M}$ ) for $24 \mathrm{~h}$. Adipose tissue was used to test the effects of dexamethasone and the CNR1 antagonists on the adipocyte lipolysis and glucose uptake. In an acute setting, isolated fresh adipocytes were pre-incubated with the CNR1 antagonist AM281 $(3 \mu \mathrm{M})$ for $30 \mathrm{~min}$, which was then present during lipolysis. Lipolysis and glucose uptake were performed as previously described [20, 24].

Total RNA was isolated from adipose tissue and the RNA concentration was determined. RNA was then converted to cDNA and relative quantification of CNR1 mRNA was performed. Frozen sections of adipose tissue incubated with or without dexamethasone were stained for CNR1 protein using immunohistochemistry.

Mitogen-activated protein kinase (MAPK) and lipolysis signaling was assessed by measuring protein levels and 
activation of extracellular signal-regulated kinase (ERK) and the key lipolytic protein hormone-sensitive lipase (HSL) in lysates of adipose tissue treated with or without dexamethasone and the CNR1 selective antagonist AM281 by immunoblotting. Immunoblotting was performed with equal amount of protein for all samples $(10 \mu \mathrm{g})$ and with the use of primary antibodies to ERK (4695S, Cell Signaling Technology (CST), Danvers, MA, USA; diluted 1:1000) phospho-ERK (Thr202/Tyr204) (4370S, CST; diluted 1:1000), HSL (4107S, CST; diluted 1:1000) and phosphoHSL (Ser563) (4139S, CST; diluted 1:1000). GAPDH (5174S, CST; diluted 1:1000) was used as a loading control for all samples.

See Supplementary Materials and Methods for details.

\section{Statistical analysis}

All data are presented as mean \pm SEM, unless stated otherwise. All statistical analyses were performed using IBM SPSS Statistics software. The Kruskal-Wallis $H$ Test was used to study differences in the CNRI gene expression in the dexamethasone dose-response. For comparison of CNRl gene expression between males and females in both SAT and OAT, data was log-transformed and one-way analysis of variance with Tukey's Multiple Comparison post-hoc test was used. Differences between treatments in gene expression, glucose uptake and lipolysis for paired samples were determined using Wilcoxon signed-rank test, while Mann-Whitney U test was used to compare differences in gene expression between independent groups. Spearman's bivariate correlation test was used to assess correlations between $C N R 1$ gene expression and metabolic parameters. Significant variables in the bivariate correlation analyses were subsequently included in multivariate stepwise regression analyses. A $p$-value $<0.05$ was considered statistically significant.

\section{Results}

\section{CNR1 gene expression in freshly harvested SAT is elevated in T2D subjects and associated with markers of insulin resistance}

Freshly harvested SAT from T2D subjects was found to have 1.6-fold higher $(p<0.01) C N R 1$ gene expression levels compared with control subjects (Fig. 1a).

In bivariate correlation analyses, $C N R 1$ gene expression positively correlated with $\mathrm{HbA}_{1 \mathrm{c}}$, fasting glucose, $2 \mathrm{~h}$ glucose and glucose area under the curve (AUC) during OGTT and a trend of positive correlation with insulin and HOMAIR (Table 1). There was no correlation with BMI or basal or insulin-stimulated adipocyte glucose uptake. After inclusion of glucose AUC during OGTT and $\mathrm{HbA}_{1 \mathrm{c}}$ in multivariate analyses, glucose AUC during OGTT (standard $\beta$ coefficient $=0.44, p<0.01$; model: $r^{2}=0.17$ ) remained the only significant predictor of $C N R I$ gene expression in SAT.

\section{2-AG and endocannabinoid-regulating enzymes are associated with markers of insulin resistance}

The gene corresponding to the endocannabinoid synthesizing enzyme DAGL-ALPHA was upregulated in T2D subjects compared with control subjects ( $p<0.05$, Fig. 1d), while DAGL-BETA was downregulated ( $p<0.05$, Fig. 1e). The expression levels of NAPE-PLD did not differ between the groups (Fig. 1f). The gene expression levels of the 2AG-degrading enzyme $M G L$ had a trend to be reduced in T2D subjects compared with control subjects $(p=0.094$, Fig. 1g) while the gene expression levels of the AEAdegrading enzyme, $F A A H$, were lower in T2D subjects compared with control subjects $(p<0.05)$ (Fig. 1h).

The SAT levels of 2-AG did not differ between T2D subjects and control subjects (data not shown), but its levels negatively correlated with adipocyte basal and insulinstimulated glucose uptake ( $p<0.01$, Supplementary Fig. 2A).

$M G L$ positively correlated with basal and insulinstimulated adipocyte glucose uptake $(p<0.05)$, HDLcholesterol $(p<0.01)$ and negatively with $\mathrm{HbA}_{1 \mathrm{c}}, 2 \mathrm{~h}$ glucose during OGTT $(p<0.05)$, fasting glucose, glucose AUC during OGTT and waist-hip ratio $(p<0.01)$ (Table 1, Supplementary Fig. 2B). Following multivariate analysis where $\mathrm{HbA}_{1 \mathrm{c}}$, glucose AUC during OGTT, HDL and waisthip ratio and basal and insulin-stimulated glucose uptake were included; $\mathrm{HbA}_{1 \mathrm{c}}$ (standard $\beta$ coefficient $=-0.36, p<$ 0.05 ) and HDL (standard $\beta$ coefficient $=0.41, p<0.01$ ) remained significant predictors of $M G L$ expression (model: $r^{2}=0.32, p<0.001$ ).

$F A A H$, positively correlated with insulin-stimulated adipocyte glucose uptake $(p<0.05)$ and negatively correlated with $\mathrm{HbA}_{1 \mathrm{c}}, 2 \mathrm{~h}$ glucose during OGTT $(p<0.05)$, fasting glucose and glucose AUC during OGTT $(p<0.01)$ (Table 1 , Supplementary Fig. 2C). Following multivariate analysis with $1000 \mu \mathrm{U}$ insulin-stimulated glucose uptake, $\mathrm{HbA}_{1 \mathrm{c}}$, and glucose AUC during the OGTT; glucose AUC during the OGTT alone (standard $\beta$ coefficient $=-0.41, p<0.01$; model: $\left.r^{2}=0.15\right)$ remained a significant predictor of $F A A H$.

Neither of DAGL-ALPHA or DAGL-BETA or NAPE$P L D$ was found to correlate with markers of insulin resistance (data not shown).

\section{Glucocorticoids increase $C N R I$ gene and protein expression in human adipose tissue}

The synthetic glucocorticoid dexamethasone $(0.003-3 \mu \mathrm{M}, n$ =3-10) increased $C N R 1$ gene expression in a dose-dependent 

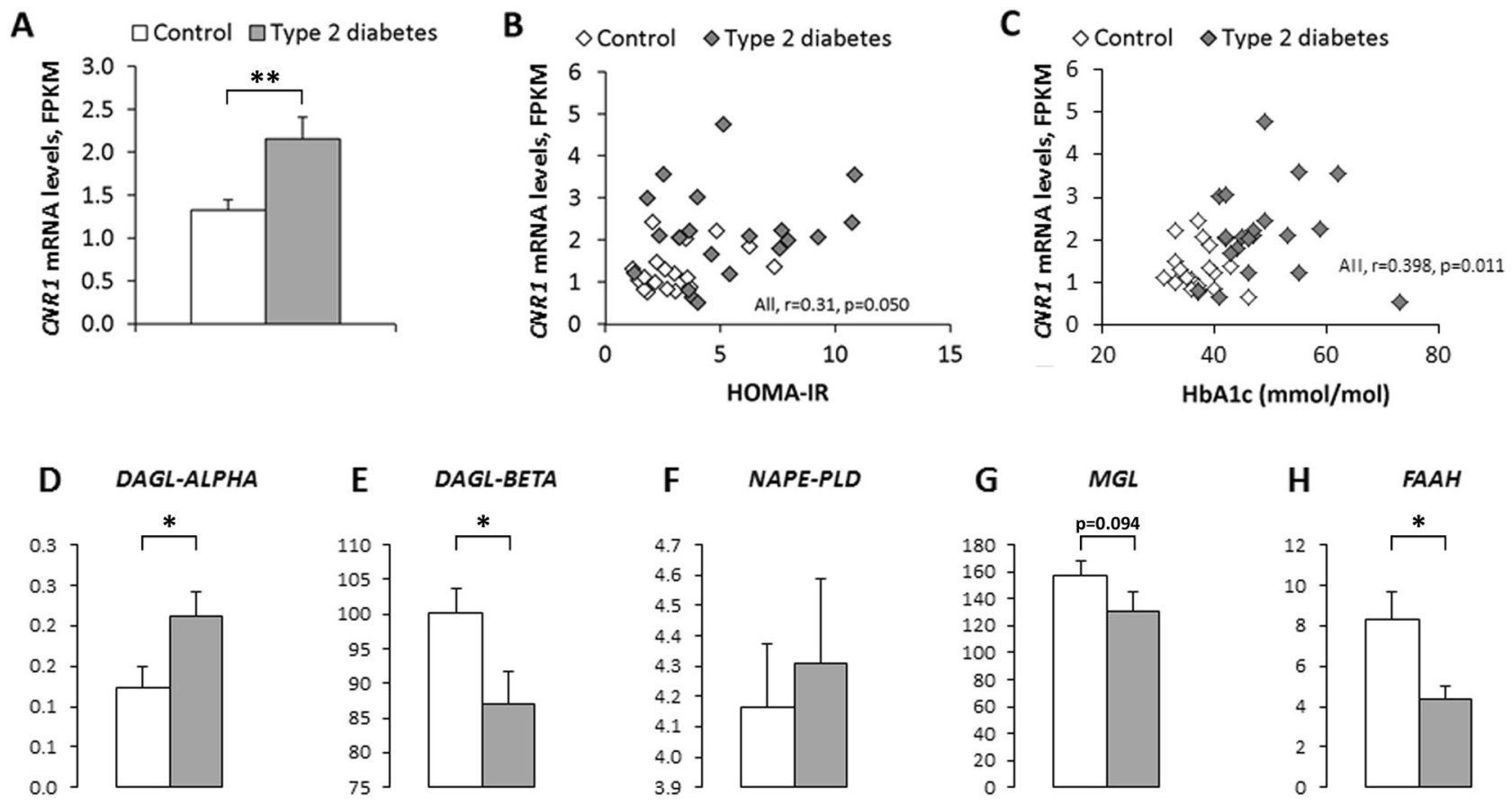

Fig. $1 C N R 1$ gene expression a is elevated in type 2 diabetes subjects $(n=20)$ compared with control subjects $(n=20)$. Bivariate correlation between CNR1 mRNA expression levels in freshly harvested subcutaneous adipose tissue and HOMA-IR b and HbAlc c. Endocannabinoid-synthesizing $\mathbf{d}-\mathbf{f}$ and degrading $\mathbf{g}-\mathbf{h}$ enzymes are differentially expressed in SAT from type 2 diabetes subjects vs.

manner in both SAT and OAT during $24 \mathrm{~h}$ incubations by up to 25- and 22-fold, respectively ( $p<0.001$, Fig. 2a). The concentration-response curves show that a maximum effect on CNR1 mRNA expression was exerted by $0.3 \mu \mathrm{M}$ dexamethasone. A similar effect was exerted by the natural glucocorticoid cortisol $(1 \mu \mathrm{M}, \quad n=5$, Fig. 2b). The glucocorticoid-induced upregulation was similar in adipose tissue from men and women. (Supplementary Fig. 4).

CNR1 protein expression in control and dexamethasonetreated SAT was assessed by immunohistochemistry. Dexamethasone treatment increased CNR1 protein amount by about 2-fold ( $p<0.05, n=5$, Fig. 2c and d) compared with control (i.e., absence of dexamethasone).

See Supplementary Results for additional details.

\section{Associations between $C N R 1$ gene expression in long- term incubated adipose tissue and metabolic parameters}

After adjustments in multivariate analyses following bivariate correlation analyses; HOMA-IR (standard $\beta$ coefficient $=0.42, p<0.001$ ), waist circumference (standard $\beta$ coefficient $=0.83, p<0.001)$ and omental adipocyte diameter (standard $\beta$ coefficient $=-0.45, p<0.001$ ) remained significant predictors of $C N R 1$ gene expression in nontreated SAT (model: $r^{2}=0.81, p<0.001$ ) (Table 2, Fig. 3 and Supplementary Fig. 3). In non-treated OAT only controls. Mann-Whitney $U$ test used to compare the differences between independent groups. $* p<0.05$. SAT was freshly harvested. $D A G L$, Diacylglycerol lipase; NAPE-PLD, $N$-acyl phosphatidylethanolamine phospholipase D; $M G L$, Monoacylglycerol lipase; $F A A H$, Fatty acid amide hydrolase; $C N R 1$, Cannabinoid receptor type 1

HOMA-IR (standard $\beta$ coefficient $=0.65, \quad p<0.001$ ) remained as a significant predictor of $C N R l$ gene expression (model: $r^{2}=0.43, p<0.001$ ) (Table 2, Fig. 3). Additionally, a negative correlation was found between the fold-change of SAT $C N R 1$ gene expression by dexamethasone, and $\mathrm{HbA}_{1 \mathrm{c}}$ $(r=-0.47, p<0.05)$ and a trend of negative correlation to HOMA-IR $(r=-0.37, p=0.061)$. In OAT, there was a trend of negative correlation between the CNRI fold change and $\mathrm{HbA}_{1 \mathrm{c}}(r=-0.35, p=0.081)$. See Supplementary Results for additional details.

\section{Effects of dexamethasone, AM281 and ACEA on lipolysis}

Incubation of SAT $(n=10)$ with dexamethasone for $24 \mathrm{~h}$ significantly increased isoproterenol-stimulated lipolysis in adipocytes by $42 \% \quad(p<0.01)$, compared with control (Fig. 4a). Addition of the CNR1-specific antagonist AM281 $(3 \mu \mathrm{M})$ to the incubation media for the last $4 \mathrm{~h}$ of incubation prevented the dexamethasone effect on isoproterenolstimulated lipolysis $(p<0.01$, Fig. 4a). In addition, dexamethasone reduced the anti-lipolytic effect of insulin, while addition of AM281 prevented this effect $(p<0.05$, Fig. 4a). Dexamethasone treatment, or co-incubation of dexamethasone with AM281, had no effects on basal 
Table 1 Association between $C N R 1, M G L$, and FAAH gene expression in freshly harvested SAT from healthy control subjects $(n=20)$ and T2D subjects $(n=20)$ and metabolic parameters

\begin{tabular}{|c|c|c|c|c|c|c|}
\hline & \multicolumn{2}{|c|}{ CNR1 mRNA } & \multicolumn{2}{|c|}{$M G L$ mRNA } & \multicolumn{2}{|c|}{$F A A H$ mRNA } \\
\hline & $r$ & $p$ & $r$ & $p$ & $r$ & $p$ \\
\hline $\mathrm{HbA}_{1 \mathrm{c}}$ & 0.398 & 0.011 & -0.387 & 0.014 & -0.397 & 0.011 \\
\hline HOMA-IR & 0.310 & 0.052 & -0.296 & 0.063 & -0.262 & 0.103 \\
\hline Fasting insulin & 0.301 & 0.059 & -0.141 & 0.384 & -0.191 & 0.237 \\
\hline Insulin AUC during OGTT & 0.044 & 0.786 & 0.083 & 0.609 & 0.093 & 0.569 \\
\hline $2 \mathrm{~h}$ Insulin during OGTT & 0.069 & 0.673 & -0.009 & 0.958 & -0.037 & 0.821 \\
\hline Fasting glucose & 0.411 & 0.008 & -0.506 & 0.001 & -0.517 & 0.001 \\
\hline Glucose AUC during OGTT & 0.375 & 0.017 & -0.446 & 0.004 & -0.430 & 0.006 \\
\hline $2 \mathrm{~h}$ Glucose during OGTT & 0.353 & 0.025 & -0.394 & 0.012 & -0.385 & 0.014 \\
\hline HDL-cholesterol & -0.310 & 0.052 & 0.427 & 0.006 & 0.139 & 0.393 \\
\hline Triglycerides & 0.193 & 0.232 & -0.130 & 0.422 & -0.191 & 0.238 \\
\hline BMI & 0.017 & 0.919 & 0.111 & 0.497 & 0.159 & 0.329 \\
\hline Waist circumference & -0.148 & 0.362 & -0.078 & 0.632 & 0.081 & 0.621 \\
\hline WHR & -0.004 & 0.978 & -0.436 & 0.005 & -0.217 & 0.179 \\
\hline $\mathrm{SC}$ adipocyte diameter & 0.069 & 0.671 & 0.177 & 0.275 & 0.181 & 0.263 \\
\hline Basal glucose uptake & -0.093 & 0.584 & 0.336 & 0.036 & 0.245 & 0.134 \\
\hline $25 \mu \mathrm{U}$ insulin-stimulated glucose uptake & -0.095 & 0.575 & 0.384 & 0.019 & 0.299 & 0.073 \\
\hline $1000 \mu \mathrm{U}$ insulin-stimulated glucose uptake & -0.126 & 0.446 & 0.385 & 0.015 & 0.367 & 0.022 \\
\hline
\end{tabular}

Bold values represent significant correlations as indicated by the $p$-values

Variables with $p$-value $<0.05$ and gender were considered to multivariate stepwise regression analysis

$H b A_{l c}$ glycosylated hemoglobin, HOMA-IR homeostatic model assessment of insulin resistance index, Glucose $A U C$ Area under the glucose curve, HDL-cholesterol high-density lipoprotein cholesterol, BMI body mass index, WHR waist-hip ratior-values are Spearman correlation coefficients. lipolysis. Results from individual lipolysis measurements are reported in Supplementary Table 4.

Freshly harvested subcutaneous adipocytes that were pre-treated with AM281 for 30 min with the compound present throughout the lipolysis experiment showed a reduced isoproterenol-stimulated lipolysis by $11 \%$ compared with non-treated adipocytes $(n=5, p<0.05$, Fig. 4b and Supplementary Table 5 for individual results).

In contrast, incubation of SAT for $24 \mathrm{~h}$ with the CNR1specific agonist ACEA increased adipocyte isoproterenolstimulated lipolysis by $17 \%$ and counteracted insulin's antilipolytic effect $(n=8, p<0.01$, Fig. 4c). Individual lipolysis measurements are reported in Supplementary Table 6.

\section{Effects of dexamethasone and AM281 on glucose uptake}

Incubation of SAT with dexamethasone for $24 \mathrm{~h}$ significantly reduced adipocyte basal and insulin-stimulated glucose uptake by 40 and $30 \%$, respectively $(n=12, p<$ 0.01, Fig. 4d). Addition of the CNR1-specific antagonist AM281 did not prevent the inhibitory effects of dexamethasone on glucose uptake.

The difference in SAT and OAT CNRI gene expression induced by dexamethasone after $24 \mathrm{~h}$ incubation was found to correlate negatively with the insulin-stimulated glucose uptake in both subcutaneous and omental dexamethasonetreated adipocytes $(p<0.05$, Supplementary Fig. 5).

\section{Effects of dexamethasone and AM281 on MAPK and lipolysis signaling}

Incubation of SAT for $24 \mathrm{~h}$ with dexamethasone or coincubation with dexamethasone and the CNR1 selective antagonist AM281 had no effects in total or phosphorylated levels of HSL or ERK ( $n=5$, Fig. 5a, b, respectively).

\section{Discussion}

In this study we show that $C N R I$ gene expression is elevated in states of insulin resistance and T2D. We also demonstrate that gene expression of endocannabinoiddegrading enzymes is reduced in T2D subjects and that this, together with elevated 2-AG levels, is associated with reduced glucose uptake capacity in adipocytes. This suggests a potential role of the peripheral endocannabinoid system to promote insulin resistance. However, whether CNR1 overexpression is a cause or a result of insulin resistance remains to be determined. 
Fig. 2 Glucocorticoids increase CNR1 gene and protein expression in adipose tissue. a $24 \mathrm{~h}$ incubation with dexamethasone $(0.003-3 \mu \mathrm{M})$ increased the $C N R 1$ gene expression in a dose-dependent manner in SAT and OAT, compared with control $(n=3$ for $0.003 \mu \mathrm{M} ; n=9$ for $0.1-0.03 \mu \mathrm{M} ; n=10$ for 0 and $0.3-3 \mu \mathrm{M})$, Kruskal-Wallis test, $* * * p<0.001$. b $24 \mathrm{~h}$ incubation with cortisol $(1 \mu \mathrm{M})$ or dexamethasone $(1 \mu \mathrm{M})$ increased CNR1 gene expression to a similar level in SAT compared with control $(n=5), * p<0.05$. c Subcutaneous adipose samples incubated for $24 \mathrm{~h}$ with dexamethasone had a higher immunofluorescence staining of CNR1 (red) compared with nontreated samples $(n=5)$. Cell nuclear DNA was stained with DAPI (blue). A representative image is presented. d Average CNR1 immunofluorescence per nucleus of 5 independent experiments
A

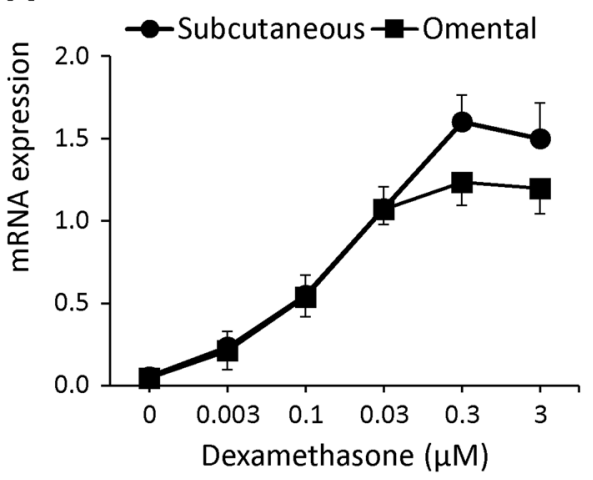

C Control $-24 \mathrm{~h}$

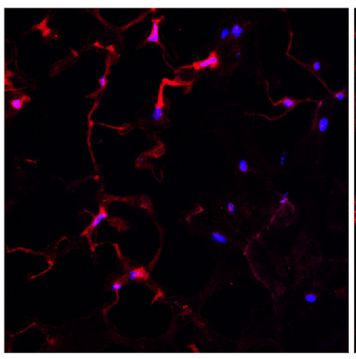

B
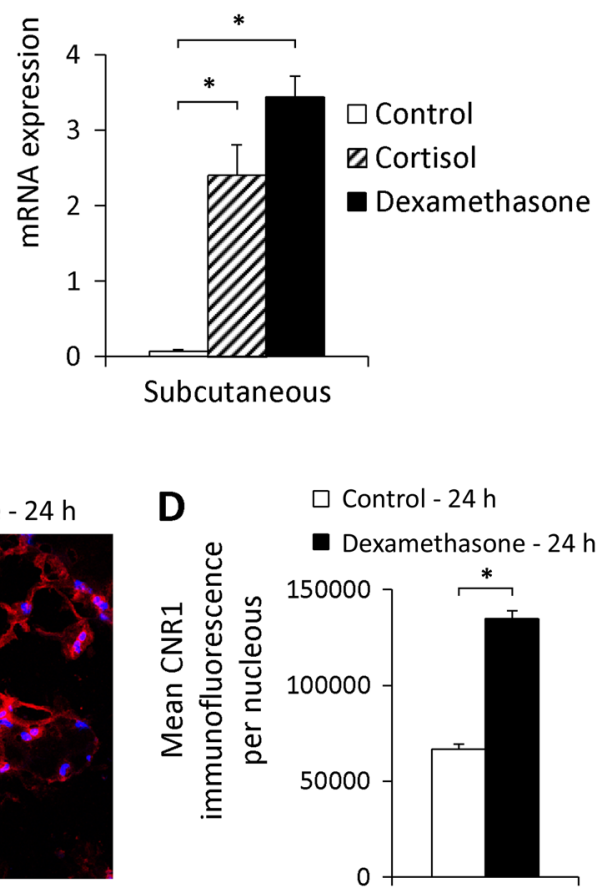

We also show that the synthetic glucocorticoid dexamethasone increases $C N R I$ gene expression in human SAT and OAT in a dose-dependent manner. Our findings also imply that subjects with elevated insulin resistance have less elevation of CNRI gene expression by glucocorticoids compared with insulin sensitive subjects, possibly due to the already elevated levels of CNRI in insulin resistance states. The ability of dexamethasone to increase CNRI gene expression was expected, as we have previously shown in a microarray study that $C N R 1$ is one of the genes with the greatest increase in expression in human adipose tissue after dexamethasone treatment [4]. However, we could not demonstrate a correlation between gene and protein expression levels across the few individuals studied. The CNR1 protein levels were increased by about 2-fold in dexamethasone-treated SAT compared with control, while the mRNA levels were increased by about 25 -fold. Although immunofluorescence is a powerful tool for determining the cellular distribution of an antigen, the extent of agreement between mRNA expression and semiquantitative immunostaining data is usually poor [25]. Additionally, post-translational modifications of CNR1 have previously been reported [26]. Overall, the results suggest that incubation for $24 \mathrm{~h}$ with dexamethasone upregulates CNR1 mRNA and protein expression in adipose tissue.
There have been discordant results concerning CNRI expression in adipose tissue. We believe that experimental design is a possible contributor to the variability. We show that after $24 \mathrm{~h}$ incubation with no additional treatments, CNRl gene expression in both adipose tissue depots is positively correlated with several parameters of insulin resistance and central obesity (e.g., HOMA-IR, BMI, waist circumference and fat cell diameter). After adjustments in multivariate analyses, HOMA-IR, waist circumference and omental fat cell diameter remained significant predictors of subcutaneous CNRI gene expression while BMI was excluded. In OAT, only HOMA-IR remained a significant predictor of CNRI gene expression. Therefore, insulin resistance, rather than obesity, seems to be associated with CNRI gene expression in both SAT and OAT. Furthermore, our data in freshly harvested SAT showed that CNRI gene expression is increased in T2D subjects compared with controls, and associated with fasting glucose, glucose AUC during OGTT and $\mathrm{HbA}_{1 \mathrm{c}}$, but not with BMI. This discrepancy vs. the incubated tissue may suggest that culturing of adipose tissue per se affects $C N R I$ gene expression. This is in agreement with a previous study showing no association between $C N R l$ gene expression in adipose tissue and BMI in freshly harvested samples [27]. In contrast, increased $C N R I$ expression with obesity has been shown in some reports $[14,28]$, but no multivariate corrections were 


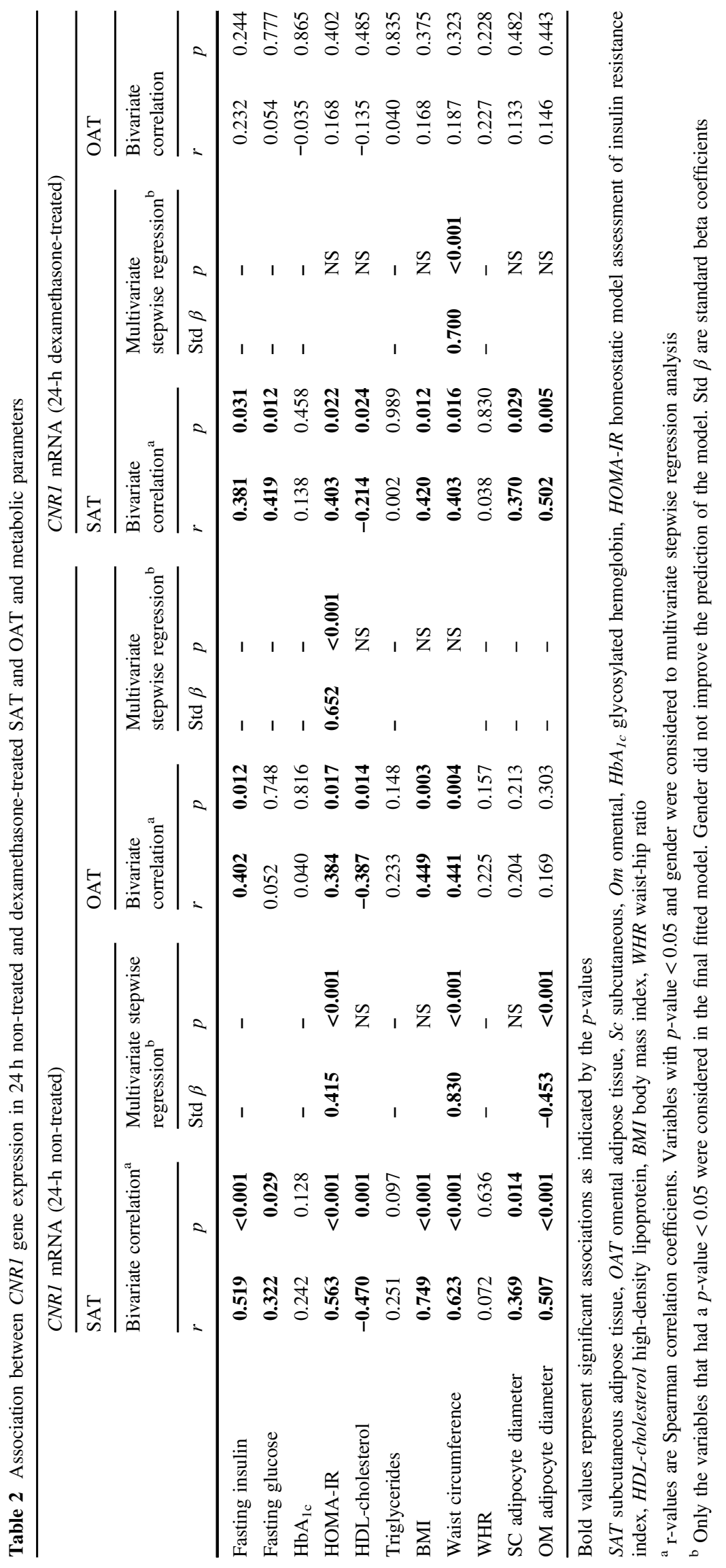




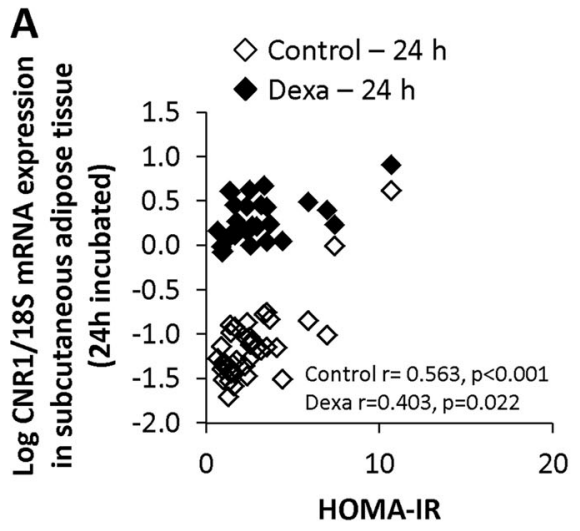

Fig. 3 CNR1 gene expression in $24 \mathrm{~h}$ incubated adipose tissue from the subcutaneous, but not the omental depot, is increased with insulin resistance. Bivariate correlation between $C N R 1$ mRNA expression in non-treated (control, $n=41)$ and dexamethasone-treated $(n=30)$ for
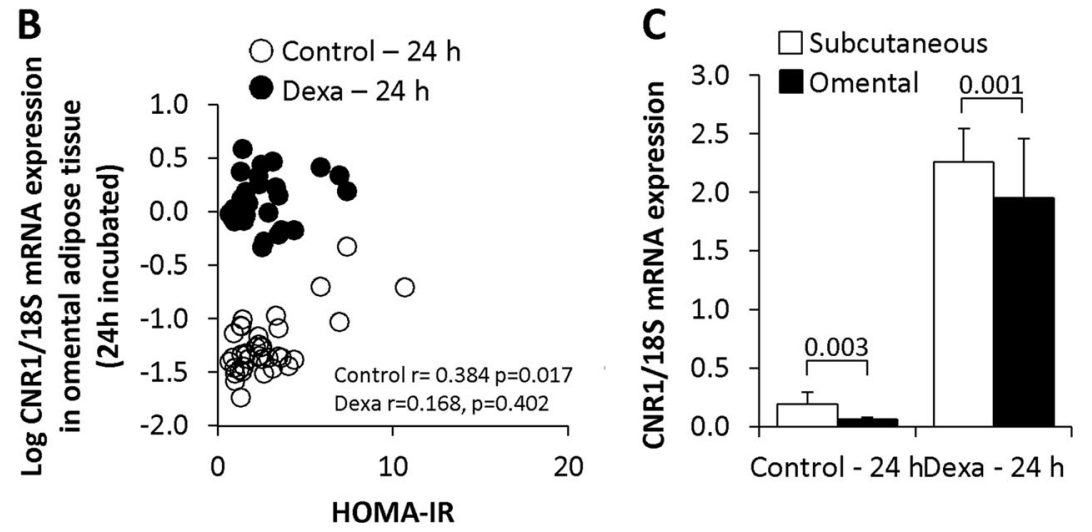

$24 \mathrm{~h}$ paired samples of SAT a and OAT b and HOMA-IR. c CNR1 mRNA expression levels in paired samples of SAT and OAT nontreated and dexamethasone-treated for $24 \mathrm{~h}(n=41$ and 30, respectively)

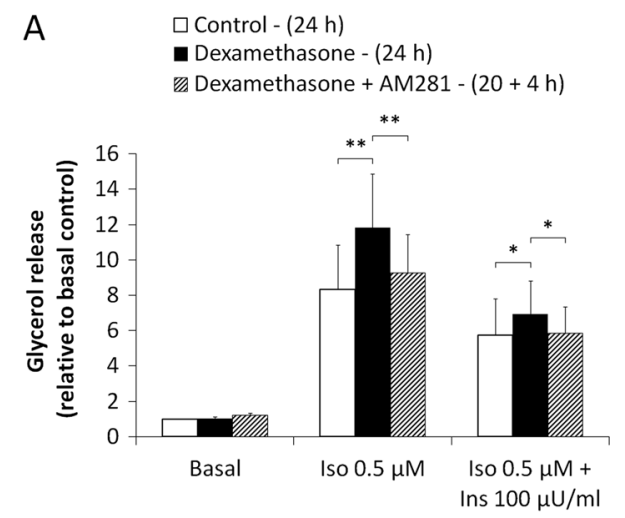

$$
\text { B } \quad \square \text { Control - (30 min) }
$$

C

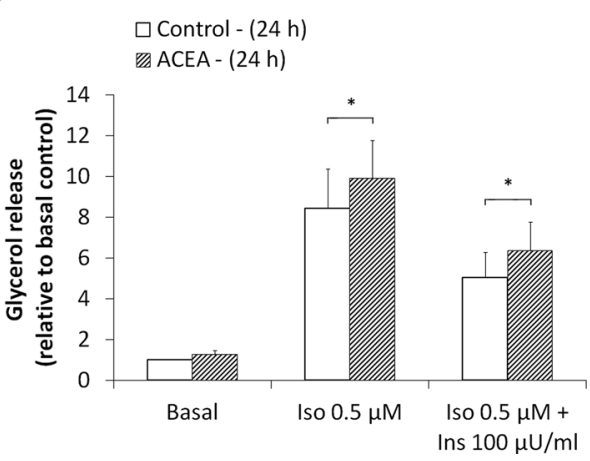

Fig. 4 Effects of CNR1 antagonist/agonist on lipolysis and glucose uptake. a Effects of long-term incubation of SAT without (control) or with dexamethasone $(0.3 \mu \mathrm{M})$ for $24 \mathrm{~h}$ or dexamethasone for $24 \mathrm{~h}$ plus the CNR1-specific antagonist AM281 $(3 \mu \mathrm{M})$ for the final $4 \mathrm{~h}$ of incubation in basal, isoproterenol $(0.5 \mu \mathrm{M})$ and isoproterenol plus insulin $(100 \mu \mathrm{U} / \mathrm{mL})$ adipocyte lipolysis $(n=10)$. b Effects of shortterm incubation $(30 \mathrm{~min}$ ) of isolated adipocytes without (control) or with the CNR1-specific antagonist AM281 $(3 \mu \mathrm{M})$ in basal, isoproterenol $(0.5 \mu \mathrm{M})$ and isoproterenol plus insulin $(100 \mu \mathrm{U} / \mathrm{mL})$

performed and the number of subjects per group is limited $(<10)$. In addition, others have found reduced CNRI

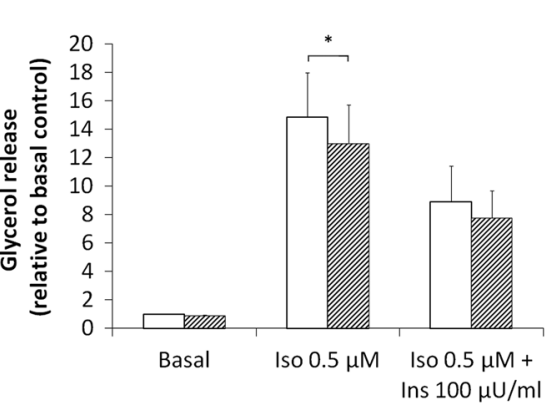

\section{D $\quad \square$ Control (24 h) \\ - Dexamethasone $(24 \mathrm{~h})$ \\ Dexamethasone + AM281 $(20+4 h)$}

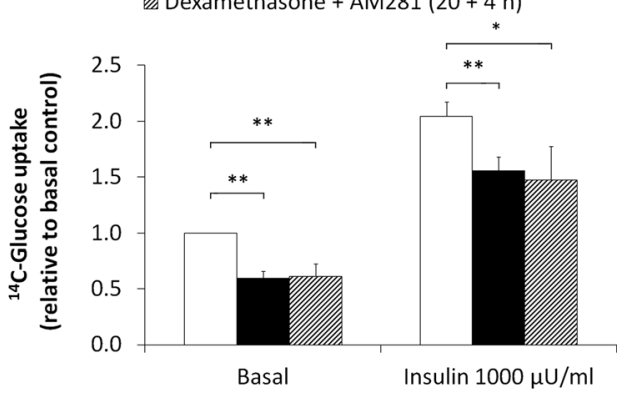

adipocyte lipolysis $(n=5)$. $\mathbf{c}$ Effects of long-term incubation of SAT without (control) or the CNR1-specific agonist ACEA $(1 \mu \mathrm{M})$ for $24 \mathrm{~h}$ of incubation in basal, isoproterenol $(0.5 \mu \mathrm{M})$ and isoproterenol plus insulin $(100 \mu \mathrm{U} / \mathrm{mL})$ adipocyte lipolysis $(n=8)$. d Effects of long-term incubation of SAT without (control) or with dexamethasone $(0.3 \mu \mathrm{M})$ for $24 \mathrm{~h}$ or dexamethasone for $24 \mathrm{~h}$ plus the CNR1-specific antagonist AM281 $(3 \mu \mathrm{M})$ for the final $4 \mathrm{~h}$ of incubation in basal and insulinstimulated $(1000 \mu \mathrm{U} / \mathrm{mL})$ adipocyte glucose uptake $(n=12)$

expression in adipose tissue with obesity, but only postmenopausal women [6] or surgical patients with variation in 
Fig. 5 Incubation of adipose tissue with dexamethasone $(0.3 \mu \mathrm{M})$ for $24 \mathrm{~h}$ or dexamethasone for $24 \mathrm{~h}$ together with the CNR1-specific antagonist AM281 $(3 \mu \mathrm{M})$ for the final $4 \mathrm{~h}$ of incubation had no effect on the total protein levels or on the phosphorylation of HSL Ser563 a and ERK Thr202/ Tyr204 b $(n=5)$. Data are means of densitometry analyses of p-HSL and p-ERK and normalized to the respective total protein levels $(n=5)$. GAPDH was used as a loading control protein
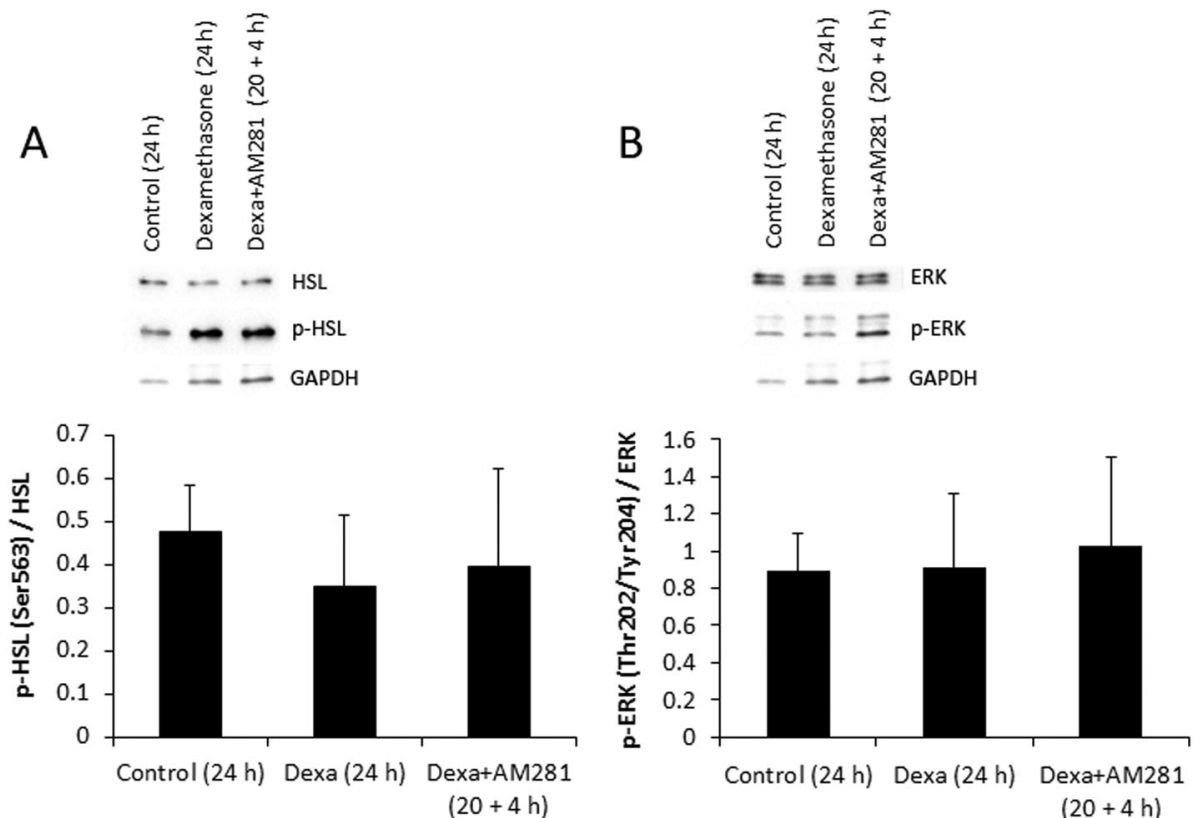

age and concomitant medication were included [13]. In our study with freshly harvested samples we had wellcontrolled T2D subjects with a tight BMI and gender matching with control subjects, which allowed us to strictly compare the disease vs. the influence of obesity on CNRI gene expression.

Activity of the CNR1 depends on the endocannabinoid levels. Therefore, we measured the levels of one of the key endocannabinoids in the adipose tissue, 2-AG, and also expression levels of enzymes responsible for synthesis and degradation of 2-AG and AEA. 2-AG levels in adipose tissue did not differ between T2D and control subjects but were negatively associated with the adipocyte glucose uptake. In addition, we found that the gene expression levels of the endocannabinoids-degrading enzymes $F A A H$ and $M G L$ were reduced in T2D subjects compared with controls, and negatively associated with $\mathrm{HbA}_{1 \mathrm{c}}$. This is in agreement with several studies showing increased activity of the endocannabinoid system in T2D and/or obese subjects [29-31]. Altogether these findings suggest a potential role of the peripheral endocannabinoid-system in adipocyte metabolism and insulin resistance. One study measuring $F A A H$ mRNA levels in SAT following hyperinsulinemic clamp showed a 2-fold elevation of FAAH mRNA in lean subjects that was not observed in the obese [32]. However, neither 2-AG levels or FAAH or MGL expression correlated with BMI in this study. We also found DAGL-ALPHA to be upregulated and DAGL-BETA downregulated in T2D subjects compared with controls. However, DAGL-ALPHA is reported to play a greater role than DAGL-BETA in 2-AG synthesis in adipose tissue [33]. It should be considered that other endocannabinoids and/or enzymes, as well as levels in other tissues and circulating levels are also of interest when exploring the activity of the endocannabinoid system.

We also explored the in vitro role of CNR1 in the glucocorticoid regulation of glucose and lipid metabolism in vitro in human subcutaneous adipocytes. To our knowledge, we show, for the first time, that a CNR1specific antagonist, AM281, partly prevents the stimulatory effects of dexamethasone on lipolysis in adipocytes. A role of CNR1 in lipolysis is further supported by the effects of the CNR1-specific agonist, ACEA, to stimulate lipolysis. Elevated CNR1 expression levels may therefore be important for the regulation of lipolysis by glucocorticoids in human subcutaneous adipocytes and might contribute to the elevation of the FFA levels in circulation as observed in glucocorticoid-treated subjects [34, 35]. This might, in turn, contribute to ectopic fatty acid deposition in tissues, such as liver and skeletal muscle, and to insulin resistance and inflammation in these tissues [36]. Moreover, the observed inhibition of dexamethasone-induced lipolysis by AM281 mimics the insulin-mediated inhibition of lipolysis. The insulin suppression of isoproterenol-stimulated lipolysis by $30 \%$ was modest. However, this suppression is similar to previous reports $[19,24]$ with identical in vitro incubation conditions. Moreover, we found that short-term treatment with the CNR1 antagonist, AM281, attenuated the lipolysis rate in freshly isolated adipocytes independent of dexamethasone-treatment. This suggests that CNR1 antagonism can regulate lipolysis independent of glucocorticoidinduced CNR1 expression levels, and also that AM281 may acutely affect lipolysis most likely by acting as an inverse 
agonist and reducing the intrinsic CNR1 activity. This indicates an involvement of CNR1 in the lipolysis regulation and suggests that peripherally restricted CNR1 antagonists via lowering of FFA levels may improve insulin sensitivity. In agreement with our findings, treatment of rats with CNR1 agonists stimulates lipolysis [37, 38], whereas a CNR1 antagonist [39] decreases plasma free fatty acids, supporting the notion of lipolysis being inhibited by CNR1antagonism in vivo.

To explore possible mechanisms involved in the effects on the CNR1 activation of lipolysis we addressed the effects of dexamethasone and AM281 incubation in phosphorylation and protein levels of ERK1/2 and HSL in adipose tissue. ERK1/2 is a protein involved in the MAPK-pathway known to be regulated by the endocannabinoid system [40]. HSL is a key factor involved in lipolysis regulation by beta-adrenergic and insulin signaling, and is regulated by ERK [41, 42]. However, ERK and HSL activation and protein levels were not affected by dexamethasone or AM281 incubation. Future studies should thoroughly elucidate underlying mediators of lipolysis and their putative involvement in the action of CNR1 and its antagonists, as well as their interaction with beta-adrenergic and insulin signaling. Indeed, CNR1 has been shown to mediate glucocorticoid effects on AMPK activity in the hypothalamus of mice [43]. AMPK, being a mediator of lipolysis, is therefore another target of interest within the context of our study.

The inhibitory effect of dexamethasone on adipocyte glucose uptake is well known [44-46]. Our in vivo data also suggest an association between adipocyte glucose uptake and the levels of the endocannabinoid 2-AG and the gene expression of endocannabinoid-degrading enzymes $M G L$ and $F A A H$ in the adipose tissue. However, CNR1-specific antagonist/inverse agonist with AM281 did not affect dexamethasone inhibitory effect on glucose uptake in vitro. In contrast to our findings, CNR1 antagonism has previously been shown to improve tissue-specific glucose uptake in skeletal muscle [17] and in nucleus accumbens [47] from rats. In contrast, other in vitro studies indicated that glucose uptake is increased in murine 3T3-L1 adipocytes and human adipocytes by CNR1 agonism rather than antagonism $[14,48]$. The discrepancies might be explained by different biological effects of the CNR1 antagonists/agonists in the different cell models used in these studies, e.g., rat skeletal muscle or brain tissue, murine cell lines or human adipocytes and in vivo or in vitro studies. In addition, different CNR1-specific compounds were used, e.g. the antagonists SR141716 or O-2050 [17, 47], the agonist WIN 55,212 [14, 47] or the endocannabinoids 2-AG or AEA $[47,48]$.

There are limitations to this study. This is primarily an in vitro study that does not take into consideration the complex cross-talk between tissues occurring in the regulation of metabolism in vivo. Although we measured the expression levels of genes corresponding to enzymes involved in the synthesis or degradation of endocannabinoids in adipose tissue, measurements in other tissues and plasma would also be valuable. That could further elucidate the overall activity of the peripheral endocannabinoid system including its autocrine, paracrine and endocrine functions $[9,49]$.

Furthermore, the collagenase isolation procedure might compromise the dexamethasone effects. However, the glucocorticoid receptor is located intracellularly and is not expected to be affected by collagenase acting in the extracellular environment. Still, it cannot be completely excluded that the dexamethasone effects are different between adipocytes isolated with collagenase and intact adipose tissue, respectively. Moreover, the lipolysis experiments involving dexamethasone and AM281 were performed only in female subjects, ruling out gender comparisons. However, as previously shown, dexamethasone treatment amplified adrenergic stimulation of lipolysis in adipocytes from women but not from men [50]. Female adipose tissue samples were therefore a priority in our experiments. Nonetheless, we plan to investigate males in future work on CNR1-mediated lipolysis regulation.

We selected the synthetic antagonist AM281 and the agonist ACEA because of their high affinity and specificity to the CNR1 receptor [51, 52]. However, other compounds with higher selectivity, e.g., SLV319 [53], could very well have more pronounced effects on lipolysis and glucose uptake than we have observed here.

Our data demonstrate that CNR1 and the endocannabinoid system in human adipose tissue is upregulated in states of insulin resistance, including T2D and glucocorticoid exposure. Also, our results suggest that CNR1 is involved in glucocorticoid-regulated lipolysis in subcutaneous adipocytes. This study gives further support to the concept of a role of the peripheral endocannabinoid system in insulin resistance, particulary in the context of high glucocorticoid exposure. The cannabinoid receptor type 1 in peripheral tissues may be an attractive drug target for the treatment of dyslipidemia and insulin resistance associated with T2D.

Acknowledgments We gratefully acknowledge the valuable technical, administrative, analytical contributions and expert advice from co-workers at Sahlgrenska University Hospital and Uppsala University Hospital. We are also grateful to co-workers at AstraZeneca R\&D for excellent scientific support.

Funding This work was supported by research grants from AstraZeneca R\&D, the University of Gothenburg/Sahlgrenska University Hospital (LUA/ALF ALFGBG-11379), the Portuguese Foundation for Science and Technology (SFRH/BD/41044/2007 and PTDC/SAUOSM/104124/2008), the Regional FoU-support Västra 
Götalandsregionen (VGFOUREG-12052), the Swedish Heart and Lung Foundation project (20100648), the Research Fund of the Swedish Diabetes Association, the Exodiab (Excellence Of Diabetes Research in Sweden), the Ernfors Foundation and the Uppsala University Hospital ALF grants.

Author contribution statement COS and MJP contributed to study design, researched data and wrote the manuscript. JLB and SS contributed to study design and researched data. PGK researched data. PK, MS, and MKS contributed to data collection. JWE contributed to study design and data collection and researched data and is the guarantor of this study. All authors reviewed the manuscript.

\section{Compliance with ethical standards}

Conflict of interest The authors declare that they have no competing interests.

Declaration of interest MKS is employed by Amgen AB and SS is employed by AstraZeneca R\&D. The other authors declare no conflict of interest.

Open Access This article is distributed under the terms of the Creative Commons Attribution 4.0 International License (http:// creativecommons.org/licenses/by/4.0/), which permits unrestricted use, distribution, and reproduction in any medium, provided you give appropriate credit to the original author(s) and the source, provide a link to the Creative Commons license, and indicate if changes were made.

\section{References}

1. World Health Organization (WHO): Obesity and Overweight fact sheet, http://www.who.int/mediacentre/factsheets/fs311/en/ (2016). Accessed 5 July 2016

2. T. Rhen, J.A. Cidlowski, Antiinflammatory action of glucocorticoids-new mechanisms for old drugs. N. Engl. J. Med. 353(16), 1711-1723 (2005). doi:10.1056/NEJMra050541

3. I. Lorraine McKay, P.a.J.A.C., PhD: Physiologic and pharmacologic effects of corticosteroids, 6th edn. Holland-Frei Cancer Medicine. BC Decker, Hamilton (ON), (2003)

4. M.J. Pereira, J. Palming, M.K. Svensson, M. Rizell, J. Dalenback, M. Hammar, T. Fall, C.O. Sidibeh, P.A. Svensson, J.W. Eriksson, FKBP5 expression in human adipose tissue increases following dexamethasone exposure and is associated with insulin resistance. Metabolism. 63(9), 1198-1208 (2014). doi:10.1016/j.metabol. 2014.05.015

5. B. Bosier, G.G. Muccioli, E. Hermans, D.M. Lambert, Functionally selective cannabinoid receptor signalling: therapeutic implications and opportunities. Biochem. Pharmacol. 80(1), 1-12 (2010). doi:10.1016/j.bcp.2010.02.013

6. S. Engeli, J. Bohnke, M. Feldpausch, K. Gorzelniak, J. Janke, S. Batkai, P. Pacher, J. Harvey-White, F.C. Luft, A.M. Sharma, J. Jordan, Activation of the peripheral endocannabinoid system in human obesity. Diabetes. 54(10), 2838-2843 (2005)

7. C. Wu, C. Orozco, J. Boyer, M. Leglise, J. Goodale, S. Batalov, C.L. Hodge, J. Haase, J. Janes, J.W. Huss 3rd, A.I. Su, BioGPS: an extensible and customizable portal for querying and organizing gene annotation resources. Genome. Biol. 10(11), R130 (2009). doi:10.1186/gb-2009-10-11-r130

8. U. Pagotto, G. Marsicano, D. Cota, B. Lutz, R. Pasquali, The emerging role of the endocannabinoid system in endocrine regulation and energy balance. Endocr. Rev. 27(1), 73-100 (2006). doi:10.1210/er.2005-0009

9. L. Cristino, T. Becker, V. Di Marzo, Endocannabinoids and energy homeostasis: an update. Biofactors. 40(4), 389-397 (2014). doi:10.1002/biof.1168

10. V. Di Marzo, Endocannabinoids: synthesis and degradation. Rev. Physiol. Biochem. Pharmacol. 160, 1-24 (2008). doi:10.1007/ 112_0505

11. S. Di, R. Malcher-Lopes, V.L. Marcheselli, N.G. Bazan, J.G. Tasker, Rapid glucocorticoid-mediated endocannabinoid release and opposing regulation of glutamate and gamma-aminobutyric acid inputs to hypothalamic magnocellular neurons. Endocrinology. 146(10), 4292-4301 (2005). doi:10.1210/en.2005-0610

12. Y.H. Jo, Y.J. Chen, S.C. Chua Jr., D.A. Talmage, L.W. Role, Integration of endocannabinoid and leptin signaling in an appetiterelated neural circuit. Neuron. 48(6), 1055-1066 (2005). doi:10. 1016/j.neuron.2005.10.021

13. M. Bluher, S. Engeli, N. Kloting, J. Berndt, M. Fasshauer, S. Batkai, P. Pacher, M.R. Schon, J. Jordan, M. Stumvoll, Dysregulation of the peripheral and adipose tissue endocannabinoid system in human abdominal obesity. Diabetes. 55(11), 3053-3060 (2006). doi:10.2337/db06-0812

14. C. Pagano, C. Pilon, A. Calcagno, R. Urbanet, M. Rossato, G. Milan, K. Bianchi, R. Rizzuto, P. Bernante, G. Federspil, R. Vettor, The endogenous cannabinoid system stimulates glucose uptake in human fat cells via phosphatidylinositol 3-kinase and calcium-dependent mechanisms. J. Clin. Endocrinol. Metab. 92 (12), 4810-4819 (2007). doi:10.1210/jc.2007-0768

15. M. Bifulco, C. Grimaldi, P. Gazzerro, S. Pisanti, A. Santoro, Rimonabant: just an antiobesity drug? Current evidence on its pleiotropic effects. Mol. Pharmacol. 71(6), 1445-1456 (2007). doi:10.1124/mol.106.033118

16. D. Jones, End of the line for cannabinoid receptor 1 as an antiobesity target? Nat. Rev. Drug. Discov. 7(12), 961-962 (2008). doi: $10.1038 / \mathrm{nrd} 2775$

17. R. Nogueiras, C. Veyrat-Durebex, P.M. Suchanek, M. Klein, J. Tschop, C. Caldwell, S.C. Woods, G. Wittmann, M. Watanabe, Z. Liposits, C. Fekete, O. Reizes, F. Rohner-Jeanrenaud, M.H. Tschop, Peripheral, but not central, CB1 antagonism provides food intake-independent metabolic benefits in diet-induced obese rats. Diabetes. 57(11), 2977-2991 (2008). doi:10.2337/ db08-0161

18. J. Tam, R. Cinar, J. Liu, G. Godlewski, D. Wesley, T. Jourdan, G. Szanda, B. Mukhopadhyay, L. Chedester, J.S. Liow, R.B. Innis, K. Cheng, K.C. Rice, J.R. Deschamps, R.J. Chorvat, J.F. McElroy, G. Kunos, Peripheral cannabinoid-1 receptor inverse agonism reduces obesity by reversing leptin resistance. Cell. Metab. 16(2), 167-179 (2012). doi:10.1016/j.cmet.2012.07.002

19. M.J. Pereira, S. Skrtic, P. Katsogiannos, N. Abrahamsson, C.O. Sidibeh, S. Dahgam, M. Månsson, U. Risérus, J. Kullberg, J.W. Eriksson: Impaired adipose tissue lipid storage, but not altered lipolysis, contributes to elevated levels of NEFA in type 2 diabetes. Degree of Hyperglycemia and Adiposity are Important. Metab. Clin. Exp. (2016). doi:10.1016/j.metabol.2016.09.008

20. M.J. Pereira, J. Palming, M. Rizell, M. Aureliano, E. Carvalho, M. K. Svensson, J.W. Eriksson, mTOR inhibition with rapamycin causes impaired insulin signalling and glucose uptake in human subcutaneous and omental adipocytes. Mol. Cell. Endocrinol. 355 (1), 96-105 (2012). doi:10.1016/j.mce.2012.01.024

21. J.S. Orr, A.J. Kennedy, A.H. Hasty: Isolation of adipose tissue immune cells. J. Vis. Exp.75, e50707 (2013). doi:10.3791/50707

22. M.T. Nakada, J.M. Stadel, K.S. Poksay, S.T. Crooke, Glucocorticoid regulation of beta-adrenergic receptors in 3T3-L1 preadipocytes. Mol. Pharmacol. 31(4), 377-384 (1987)

23. I.E. Widmer, J.J. Puder, C. Konig, H. Pargger, H.R. Zerkowski, J. Girard, B. Muller, Cortisol response in relation to the severity of 
stress and illness. J. Clin. Endocrinol. Metab. 90(8), 4579-4586 (2005). doi:10.1210/jc.2005-0354

24. M.J. Pereira, J. Palming, M. Rizell, M. Aureliano, E. Carvalho, M. K. Svensson, J.W. Eriksson, The immunosuppressive agents rapamycin, cyclosporin $\mathrm{A}$ and tacrolimus increase lipolysis, inhibit lipid storage and alter expression of genes involved in lipid metabolism in human adipose tissue. Mol. Cell. Endocrinol. 365 (2), 260-269 (2013). doi:10.1016/j.mce.2012.10.030

25. L.E. Pascal, L.D. True, D.S. Campbell, E.W. Deutsch, M. Risk, I. M. Coleman, L.J. Eichner, P.S. Nelson, A.Y. Liu, Correlation of mRNA and protein levels: cell type-specific gene expression of cluster designation antigens in the prostate. BMC. Genomics. 9, 246 (2008). doi:10.1186/1471-2164-9-246

26. H. Andersson, A.M. D'Antona, D.A. Kendall, G. Von Heijne, C. N. Chin, Membrane assembly of the cannabinoid receptor 1: impact of a long N-terminal tail. Mol. Pharmacol. 64(3), 570-577 (2003). doi:10.1124/mol.64.3.570

27. P. Lofgren, E. Sjolin, K. Wahlen, J. Hoffstedt, Human adipose tissue cannabinoid receptor 1 gene expression is not related to fat cell function or adiponectin level. J. Clin. Endocrinol. Metab. 92 (4), 1555-1559 (2007). doi:10.1210/jc.2006-2240

28. R. Sarzani, M. Bordicchia, P. Marcucci, S. Bedetta, S. Santini, A. Giovagnoli, L. Scappini, D. Minardi, G. Muzzonigro, P. DessiFulgheri, A. Rappelli, Altered pattern of cannabinoid type 1 receptor expression in adipose tissue of dysmetabolic and overweight patients. Metabolism. 58(3), 361-367 (2009). doi:10.1016/ j.metabol.2008.10.009

29. M. Cote, I. Matias, I. Lemieux, S. Petrosino, N. Almeras, J.P. Despres, V. Di Marzo, Circulating endocannabinoid levels, abdominal adiposity and related cardiometabolic risk factors in obese men. Int. J. Obes. 31(4), 692-699 (2007). doi:10.1038/sj. ijo.0803539

30. G. Annuzzi, F. Piscitelli, L. Di Marino, L. Patti, R. Giacco, G. Costabile, L. Bozzetto, G. Riccardi, R. Verde, S. Petrosino, A.A. Rivellese, V. Di Marzo, Differential alterations of the concentrations of endocannabinoids and related lipids in the subcutaneous adipose tissue of obese diabetic patients. Lipids. Health. Dis. 9, 43 (2010). doi:10.1186/1476-511X-9-43

31. I. Matias, M.P. Gonthier, P. Orlando, V. Martiadis, L. De Petrocellis, C. Cervino, S. Petrosino, L. Hoareau, F. Festy, R. Pasquali, R. Roche, M. Maj, U. Pagotto, P. Monteleone, V. Di Marzo, Regulation, function, and dysregulation of endocannabinoids in models of adipose and beta-pancreatic cells and in obesity and hyperglycemia. J. Clin. Endocrinol. Metab. 91(8), 3171-3180 (2006). doi:10.1210/jc.2005-2679

32. G. Murdolo, K. Kempf, A. Hammarstedt, C. Herder, U. Smith, P. A. Jansson, Insulin differentially modulates the peripheral endocannabinoid system in human subcutaneous abdominal adipose tissue from lean and obese individuals. J. Endocrinol. Invest. 30 (8), RC17-21 (2007). doi:10.1007/BF03347440

33. Y. Gao, D.V. Vasilyev, M.B. Goncalves, F.V. Howell, C. Hobbs, M. Reisenberg, R. Shen, M.Y. Zhang, B.W. Strassle, P. Lu, L. Mark, M.J. Piesla, K. Deng, E.V. Kouranova, R.H. Ring, G.T. Whiteside, B. Bates, F.S. Walsh, G. Williams, M.N. Pangalos, T. A. Samad, P. Doherty, Loss of retrograde endocannabinoid signaling and reduced adult neurogenesis in diacylglycerol lipase knock-out mice. J. Neurosci. 30(6), 2017-2024 (2010). doi:10. 1523/JNEUROSCI.5693-09.2010

34. G.D. Divertie, M.D. Jensen, J.M. Miles, Stimulation of lipolysis in humans by physiological hypercortisolemia. Diabetes. 40(10), 1228-1232 (1991)

35. S. Dinneen, A. Alzaid, J. Miles, R. Rizza, Metabolic effects of the nocturnal rise in cortisol on carbohydrate metabolism in normal humans. J. Clin. Invest. 92(5), 2283-2290 (1993). doi:10.1172/ jci116832
36. D.P. Macfarlane, S. Forbes, B.R. Walker, Glucocorticoids and fatty acid metabolism in humans: fuelling fat redistribution in the metabolic syndrome. J. Endocrinol. 197(2), 189-204 (2008). doi:10.1677/joe-08-0054

37. J.D. O'Hare, E. Zielinski, B. Cheng, T. Scherer, C. Buettner, Central endocannabinoid signaling regulates hepatic glucose production and systemic lipolysis. Diabetes 60(4), 1055-1062 (2011). doi:10.2337/db10-0962

38. P. Nieri, R. Greco, B. Adinolfi, M.C. Breschi, E. Martinotti, C. Nannetti, A. Podesta, CB1- and CB2-cannabinoid receptor-independent lipolysis induced by WIN 55,212-2 in male rat adipocytes. Naunyn-Schmiedeberg's Arch. Pharmacol. 368(5), 352-359 (2003). doi:10.1007/s00210-003-0831-3

39. K.A. Lindborg, S. Jacob, E.J. Henriksen, Effects of chronic antagonism of endocannabinoid-1 receptors on glucose tolerance and insulin action in skeletal muscles of lean and obese zucker rats. Cardiorenal. Med. 1(1), 31-44 (2011). doi:10.1159/000322826

40. P. Derkinderen, E. Valjent, M. Toutant, J.C. Corvol, H. Enslen, C. Ledent, J. Trzaskos, J. Caboche, J.A. Girault, Regulation of extracellular signal-regulated kinase by cannabinoids in hippocampus. J. Neurosci. Nurs. 23(6), 2371-2382 (2003)

41. A.S. Greenberg, W.J. Shen, K. Muliro, S. Patel, S.C. Souza, R.A. Roth, F.B. Kraemer, Stimulation of lipolysis and hormonesensitive lipase via the extracellular signal-regulated kinase pathway. J. Biol. Chem. 276(48), 45456-45461 (2001). doi:10.1074/ jbc.M104436200

42. H.H. Zhang, M. Halbleib, F. Ahmad, V.C. Manganiello, A.S. Greenberg, Tumor necrosis factor-alpha stimulates lipolysis in differentiated human adipocytes through activation of extracellular signal-related kinase and elevation of intracellular cAMP. Diabetes. 51(10), 2929-2935 (2002)

43. M. Scerif, T. Fuzesi, J.D. Thomas, B. Kola, A.B. Grossman, C. Fekete, M. Korbonits, CB1 receptor mediates the effects of glucocorticoids on AMPK activity in the hypothalamus. J. Endocrinol. 219(1), 79-88 (2013). doi:10.1530/JOE-13-0192

44. M. Lundgren, J. Buren, T. Ruge, T. Myrnas, J.W. Eriksson, Glucocorticoids down-regulate glucose uptake capacity and insulin-signaling proteins in omental but not subcutaneous human adipocytes. J. Clin. Endocrinol. Metab. 89(6), 2989-2997 (2004). doi:10.1210/jc.2003-031157

45. J.J. Tomlinson, A. Boudreau, D. Wu, H. Abdou Salem, A. Carrigan, A. Gagnon, A.J. Mears, A. Sorisky, E. Atlas, R.J. Hache, Insulin sensitization of human preadipocytes through glucocorticoid hormone induction of forkhead transcription factors. Mol. Endocrinol. 24(1), 104-113 (2010). doi:10.1210/me.2009-0091

46. J. Buren, H.X. Liu, J. Jensen, J.W. Eriksson, Dexamethasone impairs insulin signalling and glucose transport by depletion of insulin receptor substrate-1, phosphatidylinositol 3-kinase and protein kinase $\mathrm{B}$ in primary cultured rat adipocytes. Eur. J. Endocrinol. 146(3), 419-429 (2002)

47. B.S. Pinheiro, C. Lemos, F. Neutzling Kaufmann, J.M. Marques, C.S. da Silva-Santos, E. Carvalho, K. Mackie, R.J. Rodrigues, R.A. Cunha, A. Kofalvi, Hierarchical glucocorticoidendocannabinoid interplay regulates the activation of the nucleus accumbens by insulin. Brain. Res. Bull. 124, 222-230 (2016). doi:10.1016/j.brainresbull.2016.05.009

48. V. Gasperi, F. Fezza, N. Pasquariello, M. Bari, S. Oddi, A.F. Agro, M. Maccarrone, Endocannabinoids in adipocytes during differentiation and their role in glucose uptake. Cell. Mol. Life Sci. 64(2), 219-229 (2007). doi:10.1007/s00018-006-6445-4

49. M.H. Jantti, J. Putula, P.M. Turunen, J. Nasman, S. Reijonen, C. Lindqvist, J.P. Kukkonen, Autocrine endocannabinoid signaling through CB1 receptors potentiates OX1 orexin receptor signaling. Mol. Pharmacol. 83(3), 621-632 (2013). doi:10.1124/mol.112. 080523 
50. M. Lundgren, J. Buren, P. Lindgren, T. Myrnas, T. Ruge, J.W. Eriksson, Sex- and depot-specific lipolysis regulation in human adipocytes: interplay between adrenergic stimulation and glucocorticoids. Horm. Metab. Res. 40(12), 854-860 (2008). doi:10. 1055/s-0028-1087168

51. R. Lan, J. Gatley, Q. Lu, P. Fan, S.R. Fernando, N.D. Volkow, R. Pertwee, A. Makriyannis, Design and synthesis of the CB1 selective cannabinoid antagonist AM281: a potential human SPECT ligand. AAPS. PharmSci. 1(2), E4 (1999)

52. C.J. Hillard, S. Manna, M.J. Greenberg, R. DiCamelli, R.A. Ross, L.A. Stevenson, V. Murphy, R.G. Pertwee, W.B. Campbell,
Synthesis and characterization of potent and selective agonists of the neuronal cannabinoid receptor (CB1). J. Pharmacol. Exp. Ther. 289(3), 1427-1433 (1999)

53. J.H. Lange, H.K. Coolen, H.H. van Stuivenberg, J.A. Dijksman, A.H. Herremans, E. Ronken, H.G. Keizer, K. Tipker, A.C. McCreary, W. Veerman, H.C. Wals, B. Stork, P.C. Verveer, A.P. den Hartog, N.M. de Jong, T.J. Adolfs, J. Hoogendoorn, C.G. Kruse, Synthesis, biological properties, and molecular modeling investigations of novel 3,4-diarylpyrazolines as potent and selective $\mathrm{CB}(1)$ cannabinoid receptor antagonists. J. Med. Chem. 47(3), 627-643 (2004). doi:10.1021/jm031019q 